\title{
A Conceptual Review of Manas in Relation to Attention-Deficit Hyperactivity Disorder (ADHD) In Children
}

\author{
Review Article
}

\section{Ragamala KC $^{1^{*}}$, Pravat Kumar Dash ${ }^{2}$}

1. Assistant Professor, Department of Kaumarabhritya, S.V. Ayurvedic College, Tirupati, AndhraPradesh, 2. Professor \& HOD, Department of Kaumarabhritya, Yaswanth Ayurvedic College, Kodoli, Maharastra

\begin{abstract}
According to World Health Organization, mental disorders are to increase by $50 \%$ in 2020 , on the international level one of the main causes of morbidity in children. Children constitute about $40 \%$ of our population and in Indian studies the reported rate of psychopathology among children is $5-15 \%$. The statistical studies show that ADHD has the highest incidence among all the other developmental disorders. Attention-deficit/ hyperactivity disorder (ADHD) is a chronic condition that affects millions of children and often persists into adulthood. It includes a combination of problems, such as difficulty sustaining attention, hyperactivity and impulsive behavior. ADHD is estimated to affect about 6 to $7 \%$ of children aged 12 and under when diagnosed via the DSM-IV criteria. While treatment won't cure ADHD, it can help a great deal with symptoms. Treatment typically involves medications and behavioral interventions. In Ayurveda, the symptoms of ADHD can be correlated with the derangement in functioning of Manas and few with the lakshanas of Manasa vikaras. Thus it is worthwhile to understand the functioning of Manas in the context of the disease ADHD, which will be of primeimportance in understanding its psychopathology. Ayurvedic approach to the disease is definitely psychosomatic in nature.
\end{abstract}

Keywords: Attention-deficit hyperactivity disorder; Children; Ayurveda, Manas - Manasa vikara.

\section{Introduction}

Attention Deficit Hyperactivity Disorder is a complex psychiatric dysfunction that affects not only the individual but also the family, siblings, and even society. ADHD exhibit the symptoms like extreme and persistent restlessness, sustained and prolonged motor activity, difficulties in sustaining attention and impulsivity. Children with this disorder are prone to have learning difficulties in the schools and even unable to mingle with their peers due to poor attention and lack of persistence (1). As the condition continues, many develop minor forms of antisocial behavior particularly disobedience, temper tantrums and aggression in adulthood and will lead to problems for themselves and their families. Prevalence of ADHD across the globe is reported that $5-10 \%$ of school aged children are affected. Various studies have reported prevalence of ADHD in Indian children is between 3$8 \%$. ADHD is seen to be more prevalent in male sex than in females. It is 4-6 times more common in boys than in girls (2). Due to high prevalence and being a commonest neurobehavioral disorder of childhood, ADHD comprises perhaps $50 \%$ of referrals to child neurologists, behavioral pediatricians and child psychiatrists.

\section{*Corresponding Author:}

\section{Ragamala KC}

Assistant Professor, Department of Kaumarabhritya,

S.V.Ayurvedic College, Tirupathi, AndhraPradesh

Email address: pnragkc@gmail.com
In Ayuveda there is no exact description of any disorder that matches ADHD, but few descriptions of abnormal behaviours are found scattered in our text such as Anavasthita Chittatva, Manovibhrama, Buddhivibhrama, Smritivibhrama, Sheelavibhrama, Cheshtavibrama (3) can be correlated with the clinical features of ADHD. A balance of these temperaments results in the normalcy of behavior while their imbalance results in otherwise. Ayurveda emphasizes that Sharira and Satva (Manas) - are related with each and both interact with one another in maintaining health or ill health, comfort or discomfort of an individual's life. Ayurveda has been reputed for its philosophical bases, and management of Manasika vikaras. Thus it is worthwhile to understand the functioning of mind (Manas) first in the context of the disease ADHD.

\section{Aims and objectives:}

To analyze and interpret the clinical features of disease ADHD from different classical texts of Ayuveda.

To review the literature about the concepts of Manas from Ayurvedic science.

To compare the disease ADHD in relation to the abnormalities of the Manas and its clinical features.

\section{Materials and Methods}

Literary data was collected from different sources -Library, Classical texts of Ayurveda and modern texts including digital media, relevant articles and internet.

The materials and methods used and the modifications made was based on available literature, 
traditional experiences and expert opinions.

\section{Attention Deficit Hyperactivity Disorder (ADHD)}

ADHD is not only a disorder of impaired focus, but also includes a host of symptoms related to problems with vigilance, distractibility, impulsivity in thought and behavior, hyperactivity, and flexibility. Children with ADHD have trouble functioning at home and in school and often have difficulty making and keeping friends. If left untreated, ADHD may interfere with school and work, as well as with social and emotional development of the child. It interferes with many areas of normal development and functioning in a child's life. Attentiondeficit/hyperactivity disorder (ADHD) is the most common disorder affecting school-aged children. Its prevalence rates are increasing rapidly all over the world and have become the most extensively studied mental disorder of childhood. Criteria for its diagnosis have emerged over the past four decades, resulting in better recognition and more widespread treatment. Currently the diagnosis of ADHD is based on the criteria of DSMIV on attention deficit, hyperactivity, and impulsivity.

\section{Concept of Manas in understanding the clinical features of ADHD}

Manas, Atma and Sarira -are the pillars of the tripod of life. The world is sustained by their combination and they constitute the substratum for everything. Manas is mentioned first in the sequential order because it occupies very important place in this trio as the entire activities relating the body are controlled by it.

\section{Manas and its definition}

As per charaka:

'That which is responsible for the presence or absence of cognition is called Manasa.

Manasa is one of the nine Dravya.

- Ubhayatmaka and Atindriya.

- Manasa is Achetana but Kriyavana.

It has two Gunas - Anuttva and Ekattva;

After Sannikarsha of Atma, Indriya and Artha, the main factor whose presence or absence determines the gnanotpatti or Buddhi is Manasa.

\section{Manoarthas}

Manoarthas, also called as Manovishayas, are the aspects that require Manas for their analysis and interpretation. (4)

- Chintya: Thing requiring thought, to think about to do or not to do with purposeful or purposeless manner.

- Vicharya: It is a distinct analysis, which direct the mind to accept or reject a thing, to do right or wrong.

- Uhya: Judgement or guessing, hypothetical and logical thinking about a thing.

- Dhyeya: It is an emotional thinking about distinct thing.

- Sankalpa : It is consideration, determination of mind about thing.
Manovishayas or Manoarthas are the one, which do not require Indriya for their perception as they originate directly at the seat of Manas. Critically reviewed, these Manoarthas play key role in the thought processes, aim fixing, task completion i.e. some of the major determinants of behavioral patterns. Thus eccentricity of Manovishayas can lead to behavioral abnormalities like Anavasthita Chittatva, Manovibhrama, Buddhivibhrama etc.

\section{Karmas (Functions) of Manas}

According to Acharya Charaka

Indriyabhigraha (control of sense organs), Svanigrahah (self control), Uhya (hypothetical thinking), and Vichara (analytical thinking) are the Karmas of Manas.

\section{Faculties related with Manas}

Dhee, Dhrti, and Smriti are the three main faculties, which are closely related to Manas,

Acharya Charaka has described

- Dhee as Jnanam (knowledge of judging correctly),

- Dhŗti as Niyamātmika (controls Manas), and

- Smriti as Tattva Jnana.(memory power).

\section{Doshas of Manas}

Acharya Charaka and Vagbhata have considered Tama and Raja as the doshas of the Manas. They are having unbreakable relation with each other because Tamas cannot act without the help of Rajas.

\section{Manasika Vikaras}

The external or internal factors that affect the normal functioning of Manas can lead to psychopathology and such pathological conditions of Manas are considered as Manasika Vikaras.

The factors which helps mind to take a stable, firm, and right decision with interest of having a healthy status of the body are Dhee, Dhrti, and Smriti. Hence proper functioning of these three elements of Manas enables the mind to work at its best; in contrary, in the absence of the same, mind fails to make the right decision. This situation of mind is called as Dhee, Dhrti, and Smriti Vibramsha.

Due to Prajnaparadha (indulging in wrong things knowingly) the Manasika doshas are vitiated leading to the derangement of the functions of Manas specifically in that of Indriyabhigraha and Svanigraha leading in Vibhramsha of Dhee, Dhriti and Smrirti and finally resulting in Manasika vikaras like- Kama (passion), Krodha (anger), Lobha (greed), Moha (infatuation), Irshya (grief), Mada (arrogance) (5). Though these terms have been mentioned collectively under the description of Unmada Vyadhi, when considered individually they closely resemble some of the clinical features and associated features of ADHD.

Tridoshas, and their types are the major physiological determinants of normal functioning of the body and mind as well as that of the diseased condition. As per Acharya Charaka Vata Dosha is the main 
controller and stimulant of Manas. The Saririka doshas (Tridoshas) and Manasika doshas are interrelated with each other. Disturbed Manasabhavas, play an important role in causing various Sharirika Vyadhis and in the same way vitiated Saririka doshas become etiopathogenesis for Manasika Vyadhis. For example, Vayu is provoked by Kama, Shoka, Bhaya, thus causing vitiation of Vata Dosha and lakshanas like Alpanidra, Anidra are manifested.

Though there is no exact disease in Ayurveda that can be compared with ADHD, but the characteristics of the disease can be correlated with the abnormal presentations that are manifested due to disturbances in the normal functions of Manas- Dhee, Dhriti, Smriti Vibramsha.

\section{CHARACTERISTICS OF ADHD}

Based on the DSM - IV criteria, fourth edition of the Diagnostic and Statistical Manual of Mental Disorders published by the American Psychiatric Association (1994).

\section{ADHD is characterized by \\ - INATTENTION \\ - HYPERACTIVITY and \\ - IMPULSIVITY}

\section{Characters of INATTENTION (7)}

- Child fails to give attention to details or makes careless mistakes in school activities.

- Finds difficulty sustaining attention in tasks or play.

- Does not listen when spoken directly.

- Does not follow instructions and fails to finish homework

- Finds difficulty in organizing tasks and activities.

- Avoids or dislikes attaining tasks that require effort of thinking.

- Looses the things often.

- Easily distracted

- Forgets in daily activities

Inattention means the child will not be able to concentrate on a single task. The attention span will be poor, along with poor concentration. Due to this the academic performance of the child will be poor.

Some of the above characters of Inattention can be interpreted in the following ways in Ayurveda

- Ability of the Manas to concentrate on a single object at a time is made possible by virtue of Indriyabhigraha and Svanigraha. Acharya Chakrapani has commented that these functions of Manas are helped by Dhriti, which is the controlling factor of Manas.

- Due to Dhriti bhramsha, Manas is unable to sustain focus on particular Indriyartha and it is frequently shifting from one Indriya to another Indriya attending unwanted or irrelevant stimuli. Such similar characters are seen in ADHD i.e., easily distracted, difficulty in organizing tasks and activities, difficulty sustaining attention.
Dhee - that is the understanding and discriminating capability between beneficial and nonbeneficial and Smriti that is recollection, these both work in association with the Dhriti and lead to normal process of Jnanotpatti. Abnormalities of Dhee, Dhriti and Smriti - i.e. Vibhramsha will lead to abnormalities of Prajna - the volitional power i.e. Pradnyaparadha (6). Due to this the Manas loses its capacity of concentration, attention and learning. Such similar presentations are observed in ADHD i.e. making careless mistakes in school activities, does not follow instructions, forgets in daily activities.

\section{HYPERACTIVITY (7)}

- Fidgets with hands or feet or squirms in chair.

- Difficulty to remain seated in classroom or in other places where it is needed.

- Runs or climbs excessively.

- Has difficulty in playing or engaging activities quietly.

- Acts as if driven by a motor or in hurry.

- Talks excessively.

Hyper is a prefix, which means "more than usual" or "excessive". Activity deals with "motion" or "movement". Hyperactivity includes behavior described as restless and fidgety, especially everyday and every time. Activity is denoted by the term "Cheshta" in Ayurveda, Cheshta are executed by Vyana Vayu, the vitiated Vyana Vayu leads to abnormal Kayacheshta and Vakcheshta (8) which is manifested in the form of hyperactivity and impulsivity.

\section{Kayachesta -}

- Chapala cheshta - Fidgets with hands or feet or squirms in chair.

- Chalam asthiram (9) - Runs or climbs excessively, acts as if driven by a motor or in hurry.

- Lolam chapalam (10) - Has difficulty in playing or engaging activities quietly.

- Cheshta vibhrama - "Cheshta vibhramat anuchita cheshta bhavati"(11) this means improper and unsteady activities.

\section{Vakchesta-}

This can also be expressed by "Atana sheelata" and "Bahu bhashitvam" of Rajas dosha i.e. talks excessively.

These symptoms again are due to the Vibhramsa of Dhee, Dhriti and Smriti.

\section{IMPULSIVITY (7)}

- Blurts out answers before questions have been completed.

- Difficulty in waiting or taking turn.

- Interrupts or intrudes upon others.

Impulsivity is a sudden action that is under taken without careful thought. Some related conditions in Ayurveda are

According to Hemadri Austukyam - "Avicharyah karya pravritti" (12) this means without thinking 
indulging in activities or excitement, this can be correlated with Impulsivity i.e. Blurts out answers before questions have been completed.

Thus the core symptoms of ADHD - Inattention, Hyperactivity and Impulsivity are compared with the clinical features of derangement of Manas and its functions.

\begin{tabular}{|c|c|}
\hline \multicolumn{2}{|c|}{ Table 1: Showing the Characters of ADHD in relation to the abnormalities of Manas } \\
\hline Characters of ADHD & Characters of MANAS \\
\hline \multicolumn{2}{|l|}{ 1.INATTENTION } \\
\hline $\begin{array}{l}\text { - } \text { Making careless mistakes in school activities. } \\
\text { - Finds difficulty in organizing tasks and activities. }\end{array}$ & Dhee Vibramsha \\
\hline $\begin{array}{l}\text { - Difficulty sustaining attention in tasks or play. } \\
\text { - Easily distracted. }\end{array}$ & Dhriti Vibramsha \\
\hline $\begin{array}{l}\text { - Looses the things often. } \\
\text { - } \text { Forgets in daily activities }\end{array}$ & Smriti Vibramsha \\
\hline \multicolumn{2}{|l|}{ 2.HYPERACTIVITY } \\
\hline $\begin{array}{l}\text { - Fidgets with hands or feet or squirms in chair. } \\
\text { - Difficulty to remain seated in classroom or in other places } \\
\text { where it is needed. }\end{array}$ & Chapala Chestam \\
\hline $\begin{array}{l}\text { - Runs or climbs excessively. } \\
\text { - Acts as if driven by a motor or in hurry. }\end{array}$ & Chala Asthiram \\
\hline $\begin{array}{l}\text { - Has difficulty in playing or engaging activities quietly. } \\
\text { - Talks excessively. }\end{array}$ & Atana Sheelata, Bahubhashitvam \\
\hline \multicolumn{2}{|l|}{ 3.IMPULSIVITY } \\
\hline $\begin{array}{l}\text { - Blurts out answers before questions have been completed. } \\
\text { - Interrupts or intrudes upon others. }\end{array}$ & Austukyam-Avicharyah karya pravritti \\
\hline
\end{tabular}

\section{Discussion}

ADHD is the most common neurobehavioral disorder of childhood. It is the most prevalent chronic health conditions affecting school-aged children and often persists into adulthood and leads to significant antisocial behaviors, social dysfunctions etc. So early intervention is very necessary that can help the child.

The drugs used to treat ADHD in modern science have several side effects and even life threatening. There comes need of safe and effective treatment which can be fulfilled through Ayurvedic therapies.

Understanding of the concepts of Manas, its functions, normalcy and abnormalcy of Manas, Doshas of Manas is a prerequisite to understand the psychopathology of Manasa Vikaras.

There is no exact description of such disease in Ayuveda texts. But few Manasa Vikaras that occur due to derangement in the functions of Manas leading to Dhee, Dhriti and Smirti Vibramsha can be compared with the symptoms of ADHD i.e. Inattention, Hyperactivity and Impulsivity.

ADHD is one of the psychological disorders. For better understanding, an effort is made to compare few Ayurvedic psychological disorders with characteristics of ADHD.

The characters of Inattention - Easily distracted, forgetting in daily activities, making careless mistakes in school activities, loosing things, difficulty in organizing tasks etc.all are seen in Vibramsha of Dhee, Dhriti, and Smriti.

The characters of Hyperactivity - running or climbing excessively, Fidgets with hands or feet or squirms in chair, talking excessively etc. can be correlated with the lakshnas of Chesta Vibramha i.e. Chapala Chesta, Chalam Asthiram, Bahu bhashitam.

The characters of Impulsivity - Blurts out answers before questions have been completed,

difficulty in waiting or taking turn can be correlated with Austukyam ( indulging in activities without thinking).

\section{Conclusion}

Attention deficit hyperactivity disorder (ADHD) is one of the common psychological disorders of school aged child with few behavior problems and characterized by poor ability to sustain attention, motor over activity and impulsivity.

A basic knowledge about the diagnosis of Attention Deficit and Hyperactivity disorder in children is essential for early intervention, providing safest remedy and also for offering correct guidance to the parents.

It can be concluded that ADHD features are better understood in Ayurveda through the concepts of Manas and it can be correlated with one among the Manasa Vikaras.

\section{References}

1. Behrman, Kliegman, Jenson. Nelson Textbook of Pediatrics, 18th edition, 2007, 146-150 p.

2. Parthasarathy A and Menon PSN, IAP TEXT BOOK OF pediatrics, $4^{\text {th }}$ edition, 2009, 1049-51p.

3. Kashinath Shastry, Gorakhnath Chaturvedi, Charaka Samhitha of Agnivesha, Nidana sthana, Chaukhamba Bharatiya Academy, Varanasi, 2011, $656 \mathrm{p}$. 


\section{Ragamala KC et. al., A Conceptual Review of Manas in Relation to Attention Deficit Hyperactivity Disorder in Children}

4. Kashinath Shastry, Gorakhnath Chaturvedi, Charaka Samhitha of Agnivesha, Shareera sthana, Chaukhamba Bharatiya Academy, Varanasi, 2011, $806 \mathrm{p}$

5. Kashinath Shastry, Gorakhnath Chaturvedi, Charaka Samhitha of Agnivesha, Vimana sthana, Chaukhamba Bharatiya Academy, Varanasi, 2011, $717 \mathrm{p}$.

6. Kashinath Shastry, Gorakhnath Chaturvedi, Charaka Samhitha of Agnivesha, Shareera sthana, Chaukhamba Bharatiya Academy, Varanasi, 2011, $824 \mathrm{p}$

7. Behrman, Kliegman, Jenson, Nelson Textbook of Pediatrics, 18th edition,2007, P.146-150.

8. Kashinath Shastry, Gorakhnath Chaturvedi, Charaka Samhitha of Agnivesha, Sutra sthana, Chapter 12/8 Chaukhamba Bharatiya Academy, Varanasi, 2011

9. Lalachandra Vaidhya, Ashtanga Hridaya with the commentaries 'Sarwangasundari of Acharya
Arunadatta and Ayuurveda Rasayan of Acharya Hemadri, Sutra sthana, Chaukhambha Orientalia, Varanasi, 2002, $26 \mathrm{p}$

10. Lalachandra Vaidhya, Ashtanga Hridaya with the commentaries 'Sarwangasundari' of Acharya Arunadatta and Ayuurveda Rasayan of Acharya Hemadri, Sutra sthana, Chaukhambha Orientalia, Varanasi, 2002, 28p

11. Kashinath Shastry, Gorakhnath Chaturvedi, Charaka Samhitha of Agnivesha, Nidana sthana, Chaukhamba Bharatiya Academy, Varanasi, 2011, $656 \mathrm{p}$

12. Lalachandra Vaidhya, Ashtanga Hridaya with the commentaries 'Sawangasundara' of Acharya Arunadatta and Ayuurveda Rasayan of Acharya Hemadri, Sutra sthana, Chaukhambha Orientalia, Varanasi, 2002, 1 p . 